\title{
RETHINKING THE FUTURE OF WATER ON OUR PLANET
}

\section{REVIEW ARTICLE}

DIAS, Deusira Nunes Di Lauro ${ }^{1}$

DIAS, Adailton Di Lauro ${ }^{2}$

DIAS, Deusira Nunes Di Lauro. DIAS, Adailton Di Lauro. Rethinking the future of water on our planet. Revista Científica Multidisciplinar Núcleo do Conhecimento. 04 year, Ed. 08, Vol. 06, pp. 19-32. August 2019. ISSN: 2448-0959

\section{SUMMARY}

Considered the most important, precious and indispensable liquid for the survival of human life on Earth, water has been a cause of constant concern, because the way society has appropriated and used water resources on the planet has Committed to quality, as well as the access of many communities to this vital resource for the maintenance of life. This work intends to analyze and discuss strategies that ensure the preservation and sustainable use of water on the planet, addressing that, in some regions of Brazil and the world, are already with extreme water scarcity and, according to some authors, this problem tends to escalate more and more due to several factors, and the main ones are the rapid growth of the population and the great demand for food in the world. The laws governing water resources are being increasingly adjusted in order to preserve water resources and the whole environment. Brazil has shown that

${ }^{1}$ Graduated in the course of letters from the State University of Bahia - UNEB Campus X; Post graduated in Portuguese by the University of Vale do Cricaré and a regular student of the master's degree in education from Universidade Internacional Unigrendal online.

${ }^{2}$ Graduated in letters by Uneb, graduated in English by Unimes, post-graduated from the Integrated Colleges of Jacarepaguá (FIG), and regular student of the master's degree in education at the International University Unigrendal online. 
it is necessary to preserve, however much remains to be done to minimize the impacts caused by man to the environment.

Key words: water, scarcity, preservation, sustainability.

\section{INTRODUCTION}

Mankind has achieved, especially in this century, countless achievements never imagined by science and technology. However, the problem of water and the maintenance of life on the planet has taken much of the world's population to wonder what to do to ensure that everyone has access to water, but it does not always have an answer, because the human being is not always or almost never to be $D$ Account of the need to preserve this very precious commodity.

This concern in the future does not happen by chance, after all, data on the distribution, reserve and availability of water on the planet evidence the need to seek alternatives for preservation, as is said by VICTORINO:

It is known that almost the entire surface of the planet Earth is covered by water: from the oceans, rivers and lakes, streams and Sanghas. Water from polar ice caps, rain water, lots, lots of water... But in reality not everything is blue (the color that covers the earth - due to water-when it is seen from space), because all the water on the planet (1.37 billion $\mathrm{km}$ $\left.{ }^{3}\right)$ is constituted basically of two types: salt water of the seas and freshwater of rivers, lakes and subsoil. However, $97 \%$ of the total is occupied by salt water, unsuitable for consumption. With the so-called "water cycle" (process of evaporation and return of water to the surface in the form of rain, snow, hail or frost), the water recomposes in several ways giving life to plants and generating several Biomms following the natural course of life. Nature is wise and just because when water escapes into the atmosphere in the form of evaporation, perspiration is compensated with precipitation. This difference between the volume of water that falls and the volume of water that evaporates is about 45000 
cubic kilometers per year - which, in theory, the human being could spend. Only $20 \%$ of this total is available. Usable water is in rivers, lakes, rainwater and underground water. However, they all together correspond to only $1 \%$ of the volume of Freshwater (VICTORINO, 2007, p. 16).

Figure 1-chart-"water distribution on Earth"

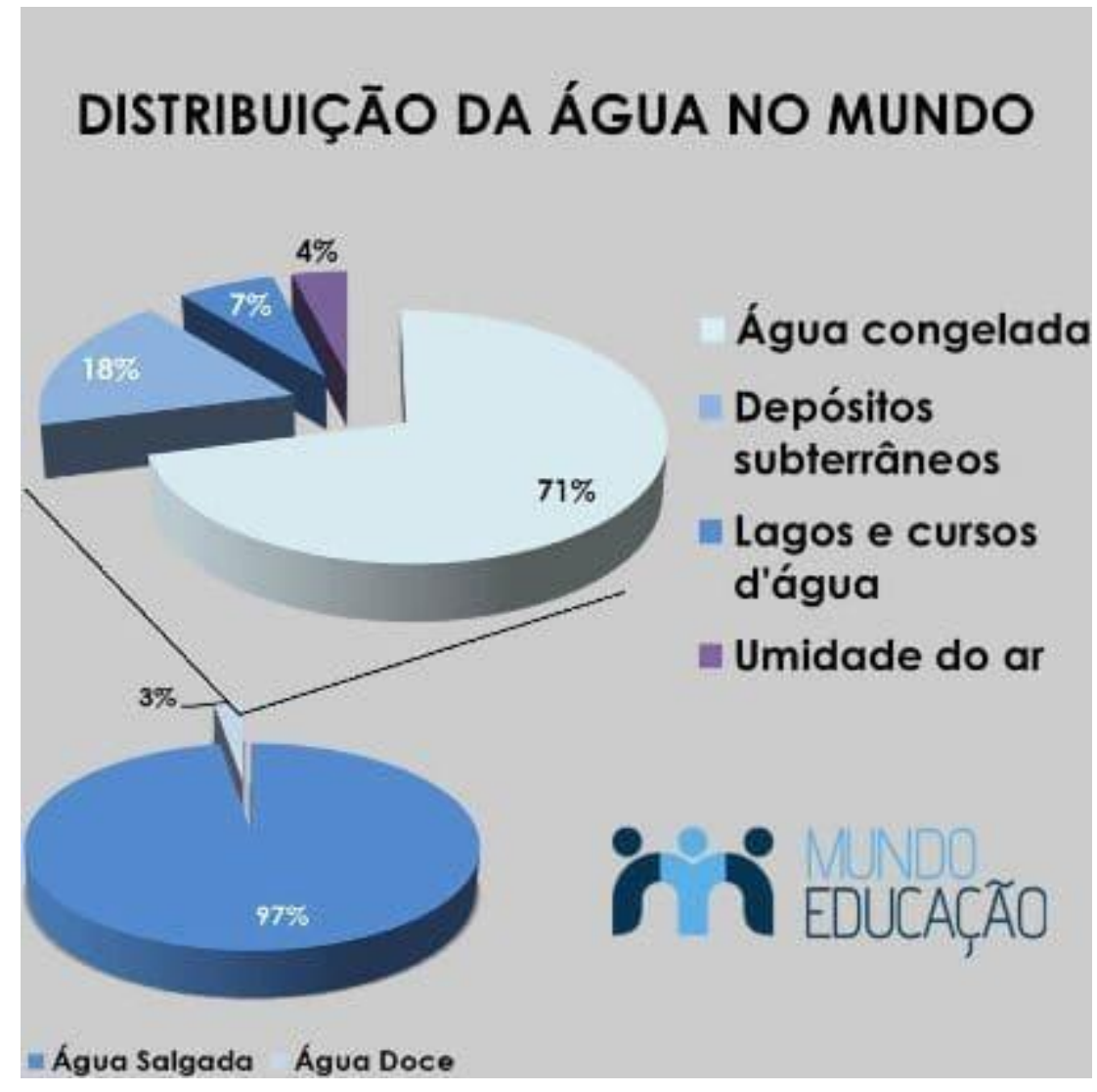

(Source: World Education Site)

When analyzing the graph above, it is observed that the amount of water available for use is insufficient, since:

If we gather 1.5 liter of water, as we find it on the planet, and divide it proportionally, the amount of fresh water available would be equivalent to a single insignificant drop. And to complicate, this little remainder is increasingly polluted, especially in large cities, due to the increase of the world population that, only in the last century became three times greater, 
which caused the increase of factories, more waste and more irrigation In the crops. According to the World Bank, about 80 countries today face supply problems. The most critical situation is in Asia where $60 \%$ of the population lives with only $32 \%$ of the fresh water available (VICTORINO, p. 17).

When analyzing all these data, it is possible to evaluate the severity of the impacts caused by the actions of man to the environment and, specifically to water, which is considered a vital resource for life on Earth. Many countries have already adopted containment and preservation postures through treaties, agreements, in order to minimise such impacts. However, a considerable portion of the world population still ignores that the future is threatened and that there will be a change, not only of mentality, but also of attitude towards the use of this resource that has been used in an irresponsible way to long history.

It is known that the world population has grown in a disorderly manner, and this also demands a considerable increase in industrial agricultural production in an attempt to guarantee food for all, which imposes increasingly intense pressures on the environment. In view of this, it is necessary to find strategies that cancel the impacts, since a population of more than eight billion people is expected for the year 2020:65\% in coastal areas and $60 \%$ in cities with more than 2.5 million people. In addition, the use of water supply increased enormously in a short period of time: While the renovation did not change the water resources level, from 1900 to 1995, in counterdeparture, the amount used increased to six times more (twice the Population increase index) and two times more since 1975. Of the total water consumed on the planet, agriculture absorbs a global average of $70 \%$ of water supplies, and in the underdeveloped countries the percentage is even higher by registering an increase of 80 to $90 \%$, with an average of $20 \%$ for the industry and $10 \%$ for domestic uses and OR Tros.

When analyzing the situation of Brazil within this context, it is even more evident that water has not been used in a rational way, which compromises and much the supply and quality of life in many regions of the country. 


\section{WATER CONSUMPTION IN THE COUNTRY}

Figure 2-chart - water consumption in the country

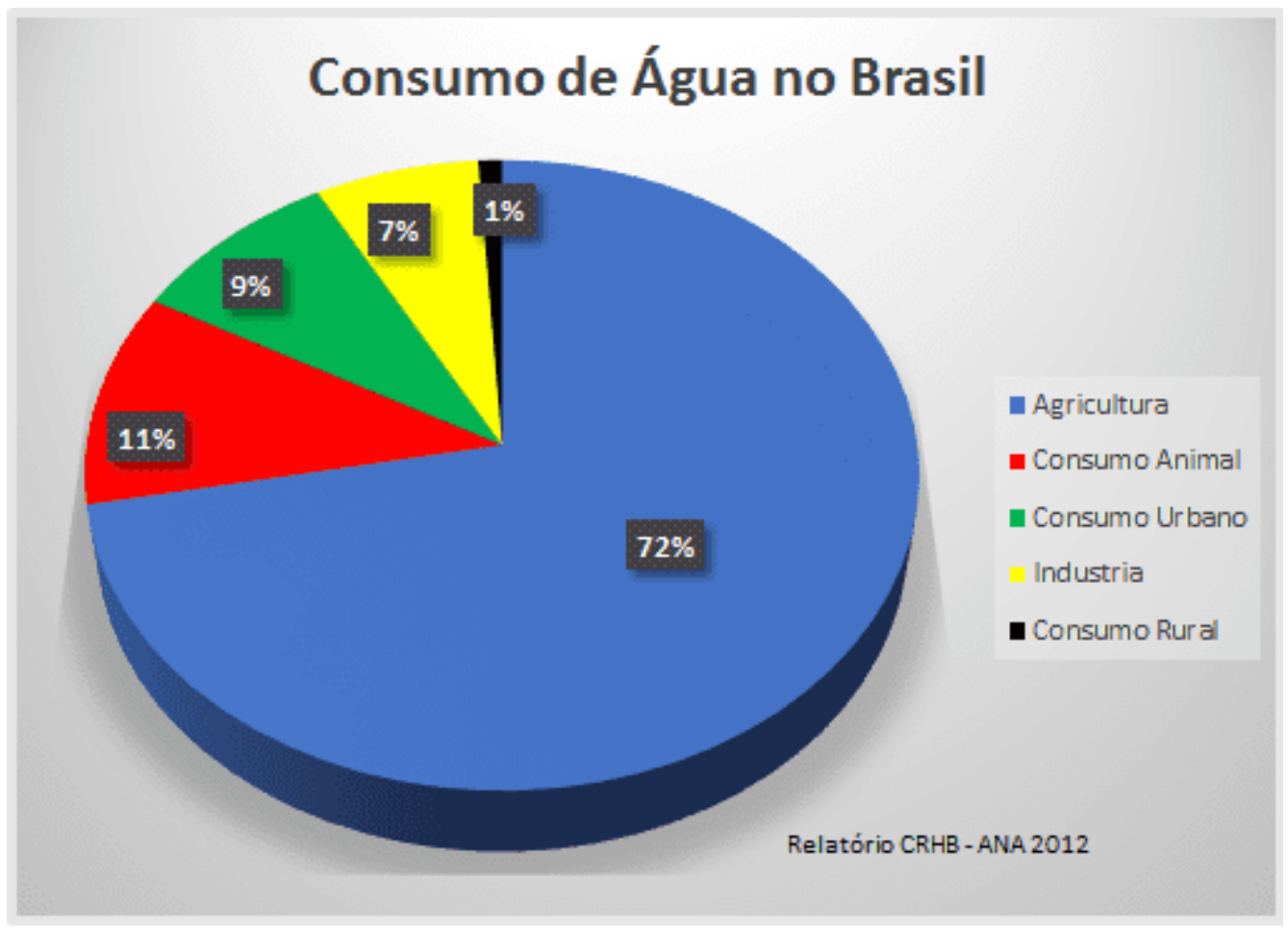

(Source: EOS Consultants)

The chart above points to agriculture as the great villain in the consumption and waste of water in Brazil and, although the country is a pioneer in approving laws that limit consumption and imposes some sanctions on those who commit abuses in the consumption and use of water, it is also known that there is insufficient oversight on the part of the rulers to ensure that the laws are respected, that is, although there are laws of preservation, in practice is far from happening.

Nowadays, despite the legal concept of good common use of the people, water is a resource, for many, of economic value. This results from the growing demand for water for the various uses, which accompanies the urban and industrial development of the countries. Nowadays, the great problems related to water do not happen because of nature, but arise from misuse with waste and improvident, as well as widespread pollution that threatens the environment. 
The water code, the law greater than discipline the use of water in Brazil is July 10, 1934, is already a certain age, but not so it is no longer current because it classifies legal categories, discriminates the uses of water and its precepts and, above all: seeks to ensure the general interests of society. In the old code it was possible to find private water domain in some cases, but this was extinguaged from October 1988, when all bodies $D$ ' water became public domain.

\section{THE QUALITY OF THE WATER WE CONSUME}

The quality of water available on the planet is another aspect that has also been the subject of concern on the part of health agencies worldwide as diseases are avoided when using decontaminated water. The quality of the water has decided the luck of some regions around the world in economic character, mainly in relation to the manufacture of beers. But it is not only in the branch of breweries that the purity of water is important, it is also necessary in the industries of tapestries, in tannery, in the fabric industry and in the precious stones. In addition, the quality of the water will determine the quality of life of its consumers. When there is no proper drinking water for human consumption, the result is the high rate of diseases and other problems arising from them. This is a concern that in the past determined the success or failure of the most developed nations, as Célia Jurema says:

Man always cared about water. For 4,000 years B.C., the first laws that were known were codes that regulated the use of water, written by the Sumerians. But not all civilizations were careful about that. Records show that the Maya had to abandon the city of Tical, located in full tropical forest, where the ruins of the Pyramid of the Sun were found, because they did not know how to properly store the water, besides producing growing erosions and large Deforgings because they used wood even in the inner structures of the columns of their gigantic temples. In Mexico, in the Yucatan Peninsula, the rain god, Chac, was revered and, whenever water became scarce, new temples were erected in the hope that the god of the waters would save the Maya from droughts. They are often found, motifs of the Mayan rain God at the base of the pyramids. The 
coexistence with the rivers brought wisdom to the populations throughout the development of mankind, the pharaohs, planned their cities leaving the riverside areas Free "(VICTORINO, 2007, p. 19).

Since more remote times, water has always been one of the most important social regulators. The structures of peasant societies and village communities, where living conditions are intimately linked to the soil, were organized around the water. There were rare cases in which all members of a community were at the same level in relation to water - access to it almost always involved inequality. This leads us to understand how it is the relationship of human beings with water and with one another due to water. The man, however, took a long time to care and care effectively about the quality of the water - many still today did not realize that, more days less day, scarcity will be a reality, and continue to use water indiscriminally is for simpl tasks Es how to wash the car with hose or sweep the sidewalk with Jets $D$ ' water. Others still play all sorts of waste in lakes, rivers and streams. How long will society continue to act so inconsequential and irresponsible? The water, this mineral that we both know and which is part of us, has existed for at least 3.9 billion years. The "rational being", in a few generations, has already managed to compromise, not only the quality, but also the quantity of this natural spring. One can evaluate the degree of development of a people by the quality of water and sanitation services that are offered to the population. The capacity to support human life and society is complex, dynamic and varies according to how man manages environmental resources. It is strange that the wise priests of antiquity did not perceive the existing correlations between water supply and forest conservation. At that time, planting was the privilege of the princes only, it was not through their ' shining ' heads that would require fronts of planters to reforest the raved lands:

8000 years ago, Brazil had $9.8 \%$ of the world's forests. At the beginning of the $21 \mathrm{ST}$ century, this percentage fell to $28 \%$ and, worse, the 64 million of square kilometers of existing forests before the demographic and technological expansion of humans remain less than 15.5 million, about 
$24 \%$. This means that more than $75 \%$ of the world's forests have already disappeared... EBC

Restoring degraded natural resources is more difficult than its conservation; And, many of them, like water, cannot be restored, when it ends there is no turning back, when it ends is forever. The false illusion that water will never end apparent in nature perhaps justifies, in part, the historical neglect of human beings in their relations with water resources. It is known that there is not so much drinking water available as the landscape makes us see. What we actually have as drinking water is only $0.03 \%$ of the total water on the planet. This insignificant amount should receive all possible care, however, this is not what we see on almost every continent, after all, the main aquifers are being exhausted with a faster speed than their natural ability to recover.

\section{THE INDISCRIMINATE USE OF WATER AND THE COMMITMENT OF THE QUALITY OF LIFE OF MANKIND}

It is not necessary to go too far to perceive situations of waste and devaluation of natural resources. With the water is still the same, and in theory the idea of preserving this resource despite being somewhat emphasized, in practice there is no great mobilization to prevent foreseeable consequences of a future with water scarcity. The following quotation clearly defines the situation in question:

One of the main challenges of society in this 21 st century concerns the urgent need for the preservation of water resources in quality and quantity, in a scenario of population increase and low sustainability of production processes and consumption.

$[\ldots]$ These forecasts of population growth and estimates linked to food production, conservation and distribution consider that if the world population reaches 10 billion inhabitants in the next 50 years, we will have $70 \%$ of the inhabitants of the planet Addressing deficiencies in water supply, affecting about 1.06 billion people who will not have even water for basic food (SILVA, 2009, p. 1). 
While in many countries around the world water has already become a dispute generating diverse conflicts, Brazil has not yet realized the great responsibility we have with the quality of life of future generations. According to Célia Jurema Aito, Brazil is a privileged country in terms of water availability as it counts with $28 \%$ of South American availability and $12 \%$ of the world's water reserves. In Brazilian territory, $72 \%$ of the water is located in the Amazon Basin. The Amazon River has 6,885 kilometers of extension and is the world's largest in water volume, dumping 175 million liters per second in the Atlantic Ocean. However, it cannot be forgotten that the growth of the population causes the risk of scarcity to reach us as well. According to Célia Jurema, between 1970 and 2000, Brazil went from an urban population of $55 \%$ to $82 \%$ of the total population. It is known that more than 1.4 billion people do not have access to drinking water and yet another 2 billion do not have any type of basic sanitation.

As modern man evolved into technology, he ceased to have contact with his natural essence, went on to live ever farther from his base, nature, and to become an anxious and irritated being. The collective imbalance that our planet faces profoundly represents an imbalance of the individuals who make up the world population. This imbalance relates to a failure in the process of evolution of man who distout himself from his origins, seeks, most of the times, his individual welfare, forgetting that we are part of a living organism called "society" and for it to Develop effectively, it is necessary to ensure the good of all and not only of oneself. In large cities, it is perceived that more and more people feel alone, helpless, even living in the midst of the crowd, which makes them more individualistic and selfish every day. And although nowadays, there is an idea of preservation, at least in the advertisements of many companies that aim to raise the flag of preservation a "business marketing" that is profitable, the great truth is that little do for the preservation of the environment and Consequently water in the country. Hence, we feel the inefficiency, despite so many efforts, of our rulers, of nongovernmental organizations and even of the population itself in relation to the environmental issue, since all the work is done basically to solve the problems When the process of change and improvement should start at the internal level of each person. 
Unfortunately, the world's population that occupies more and more space on the planet is directly responsible for the degradation of rivers, coastal areas, oceans, beaches and, as this population does not grow, the volume of garbage has become bigger every day. To get an idea of the problem, only Americans produce 212 million tons of garbage per year and move nearly 3 million of plastic bottles per hour. It takes a conscience to dispose of this kind of rubbish in places for recycling. In Brazil, the national Solid Waste policy (Federal Law 12.305/2010) determines that all material produced by domestic and commercial activities that will be possible to collect by public cleaning services, must be forwarded to the destination End only when it is not possible to reuse it, either through recycling, re-use, composting or power generation. Where there is no viable technology, waste must be destined for landfills. However, of the volume produced in 2016, almost 30 million tons did not have the appropriate destination, which represents a percentage of $41.6 \%$ of the total generated, which transforms the solid waste into a serious environmental problem, because inadequate disposal can Loading this material into streams and rivers and consequently reaches the oceans, in addition to the problem of dumps, the impacts on public health among other negative effects.

On average 80 million tons of municipal solid waste are produced, being almost 470 kilos per inhabitant, where $60 \%$ of this total is recyclable material. However, only $3 \%$ of the garbage produced is forwarded for recycling.

The impression is that everywhere the surface waters are being polluted with a frightening variety of urban, industrial and agricultural waste. Even in industrialised countries, where legislation on water quality is in place, pollution is still a problem that bothers. In the United States, it was found that $60 \%$ of the lakes surveyed are polluted by nutrients from fertilizers and animal manure, which is causing almost massive death of fish, in addition to degradation of water quality. In Canada, 20000 lakes are hit by acidic rains.

Brazil's demographic and economic growth in recent years has used water resources far beyond its capacity to support both quantity and quality. The serious water management problems are caused by the disorderly expansion of urban populations and the restricted availability of water resources, in addition, public policies aimed at 
preserving the waters are insufficient in the face of Consumption and utilization demand. The occupation of the flat spaces, close to the rivers and without control, caused for years and years, small floods in a large number of cities in the south and southeast, in Brazil. In the years 80, several riverside floods occurred and with major losses, mainly in Paraná, Santa Catarina, São Paulo and Minas Gerais. In our country there is a great diversity of situations, with plenty of water resources in the North and Midwest regions and scarcity in the northeast and southeast regions, in opposition to the greater concentration of demand, along with the southern region. Urban development also increases water-resistant and low-absorption areas through residences, walks, streets, parking lots and even parks. Since rainwater cannot infiltrate the soil, the additional volume drains into the drainage system towards the rivers. In the decade of 70, there was great hope that it was possible to plan the growth of cities and plan their future harmonically. However, 37 years later, it appears that urban planning in Brazil, or even abroad, was atrophied leading to the accumulation of problems.

The Brazilian waterfront is the victim of real estate fury, especially in Rio de Janeiro, in addition to the beaches of the Northeast and south. Rampant growth provides the emergence of villages and favelas where drinking water is not found and, much less, sewage. Rio de Janeiro and São Paulo, the two largest Brazilian cities, have serious deficits of sewage treatment network and, despite having international loans, fail to reduce the high level of pollution of Guanabara Bay and the Tietê River, this Due to the lack of awareness of the population and an environmental education program that stimulates changes in the behavior of individuals.

The largest cities in the country manage their water resources poorly. In 1997, the World Bank offered US $\$ 40$ billion for sanitation companies. Almost $100 \%$ of the money still remain intact because Brazilian companies do not fall under the minimum technical requirements to receive loans-affirmation of geologist Aldo Rebouças, of the Mineral Resources Research company - this because the bank Determines that companies have a maximum of $20 \%$ loss in water distribution networks. In São Paulo alone, in 2001 , losses were $30 \%$. 
Environmental degradation is one of the most critical aspects of the process of deterioration caused directly and indirectly by man. Regions that previously had amounts of water resources, today begin to give signs of scarcity, and the explanation is the waste with excessive exploitation, the silting of rivers and the pollution of sources. And all these problems originate almost always in the explosion of industrial agriculture that serves to feed the millions of inhabitants of the cities. It is a fact that urbanization and rampant growth of cities significantly increase the consumption and misuse of water.

\section{WHAT TO DO IN THE FACE OF SUCH WASTE?}

Depolluting water is not only a technical problem, but also of economic and social order, because there are insufficient resources to implant the liquid wastewater purification systems with the available technology. It is known that states have been able to capture resources through international banks and take the first steps in favor of our sources, such as in Rio Grande do Sul, with the Pró-Guaíba (state program) and Guaíba Vive, in the capital Porto Alegre, as a Reference to the problem of water resources. However, much still needs to be done, because water is needed in all aspects of life. Freshwater resources constitute an essential component of Earth's hydrosphere and an indispensable part of all terrestrial ecosystems, and its widespread scarcity, gradual destruction and increased pollution of water sources in many regions of the world Demand awareness and changes in attitudes towards water. And while many squandere and waste, others already suffer the consequences of water scarcity. Distribution inequality and waste are two strong reasons that partly explain why 1.4 billion people - almost five times the population of the United States - do not have access to drinking water, and water is a primary factor for health. It is also known that $60 \%$ of water resources are situated in only nine countries, among them Brazil, but are 80 countries representing $40 \%$ of the world population, who suffer from water scarcity. However, it does not mean that the United States, Brazil, Russia, South Africa or China, considered water-rich countries, are not free from problems of lack of ' water. 
As for the waste, according to Rodolfo F. Alves Pena, Agriculture is responsible for the absorption of on average worldwide, $70 \%$ of water supplies, and this index goes to 80 to $90 \%$ in the underdeveloped countries. The drinking water is lost on average $50 \%$ in the leaks of distribution systems and if nothing is done in the sense of behavioral changes, in the year 2025 will be more than 4 billion people who will not have access to this very precious and essential for life.

Therefore, it is necessary to analyze the issue of non-waste of water in the rural environment in an integrated way, in which several factors influence the change in the habit of the producers, in the case of the proper use of hydric resources, as Oliveira (2008) discusses:

The decision and option for the most efficient use of natural resources in general and water in particular should be given in an integrated manner and associated with management tools at all relevant levels. Only in this way will it be possible to reach a level that enables an adequacy of supply and demand with a view to the rational use of such a precious resource. (OLIVEIRA, 2008, p.3)

This awareness needs to occur in the various areas of society, regardless of the social, cultural and intellectual condition of individuals. That's because today, a European citizen consumes 150 liters of water a day, while an Indian has to settle for only 25 liters a day. An American consumes 3,000 liters of water a day.

It is good to emphasize that the waste of the paper is more an aggravating in the felled of trees, as well as the consumption of water, since, to produce a ton of virgin fiber, it is necessary 44000 to 83000 liters of water. It is necessary to encourage the use of recycled paper, since, for each tonne of paper used, almost a ton of new paper can be produced (more efficient than the ratio 2-3.5 tons of trees to produce a ton of virgin paper). The process of environmental education should be stimulated.

Freshwater, a finite resource, is highly vulnerable and of multiple uses, so it must be managed in an integrated manner with effective coordination and implementation 
mechanisms. In the plans for its use, it is necessary to emphasize the protection, conservation and sustainable and rational management based on the needs and priorities of each community. The evaluation of water resources is the practical basis for its integrated and sustainable management, as well as a balanced examination of the needs of the population and the environment.

For all the reasons presented here, it is necessary to keep in mind that water is the most precious commodity of this century, this, however, does not mean that one should transform the "source of life" into a monetary system, generator of so many conflicts, but rather unite efforts in favor of conscious consumption and the preservation of this vital resource to guarantee the quality of life of future generations.

\section{FINAL CONSIDERATIONS}

Sustainability is the relationship between human economy systems and the environment. The actions of men must be in tune with the environment, guaranteeing maintenance and preservation to maintain the diversity, complexity and functioning of the ecological system that keep us alive. And thinking sustainably is necessary, because natural resources are finite. Moreover, the quality of resources has become increasingly worse due to the increase of the population and the lack of public policies aimed at preserving them. As an example, it is estimated that approximately 12 million people die annually due to problems related to water quality.

The only way in which most countries can treat the growing pollution of their water resources is the implementation of integrated management strategies, which not only help to clean the courses D ' Water, but in the first place, also prevent pollution. So far, very few countries have actually been able to practice such changes. You have to be alert. We will have to avoid waste, disrupt polluting processes and create new ways to control, capture and distribute.

It takes a cultural and ethical response. The situation by which the world is passing, is nothing more than a more sophisticated lifestyle, where what one wants "must have", thus causing the acceleration of factories and industries that are among the largest 
users of water only losing to agriculture and polyester use Plastic. In the TWENTIETH century the population grew three times, while water consumption increased by six. Even us Brazilians, who have $16 \%$ of all the water in the world, are suffering from rationements due to poor administration of resources and inadequate infrastructure. The arid countries face more frightening challenges like the Middle East, where there are areas where scarcity limits socio-economic growth.

Joint management measures for the use of land and water resources should be more frequent in order to increase the efficiency of the use of irrigation water, thus avoiding soil erosion, flooding, sedimentation, salinization and the harmful effects of Pesticides and fertilizers in organisms. In addition, environmental degradation has generated an emerging environmental pathology, and diseases such as cholera, and dengue, have become more forcefully caused by contamination of air, water and soils, as well as by the use of toxic and hazardous substances, such as Pesticides and other special care products. As we have seen so far, degradation is not only of the environment, but also of the human being, whose values are lost, where the necessities are no longer the basic, and rather the superfluous, where being wrong is the right one. This is where we will see environmental education as a priority to achieve the goals of sustainable development. The Tbilisi conference held in 1977, dealing with environmental education internationally, makes seeing the EA as the formation of a consciousness founded on a new ethic that will resist all exploitation. This is what mankind needs, to take a turn in its actions, in its investments, in its attitudes, in its values, to realize that it is not only thinking of itself that it will be able to give a healthy future to its generations.

We know that the man is the main causer of so much imbalance. The man disturbed so completely the natural environment where he moved that he no longer knows his place in this system, except, of course, as a disorder factor. So far our attempts to dominate the medium consisted of simple landscape reforms, carried out clumsy and irreflectiously; While other human activities have produced harmful, unforeseen and poorly understood side effects. All the oceans have been polluted by humans, the atmosphere and even the remote glacial layers. Most of the rivers are more or less polluted and many of them, such as the Tietê River and the Tiber, were transformed 
into open-air sewage. Barbie Nadeau, Journalist of Newsweek in 2002 was in Rome and gives her testimony about the Tiber "... They float dead fish decimated, not known for what. The stench is everywhere, an oily residue makes the Eels and the dead Carps Glow "and concludes:"... If a river is the symbolic line of a city's life, then Rome is in a rather bad situation. " The case is not to dominate the medium, but to know if nature can be preserved with a certain appearance of order and if civilization is able to survive the transformation that provokes in nature. Cultural evolution has gradually led us to acknowledge that the humanization of the planet can only succeed if fundamental ecological laws are respected.

It's time to start thinking about changing habits. To feel that we form together a single chain; If you break a link, the chain will have no more sense. Everyone needs everyone. The Indian scholars, thousands of years ago, already said that the whole is contained in the parts and, as much as things seem diversified and plural, in fact, they are aspects of the same and only reality. Here is a sentence to be mediated, by all of us, so that we can understand the dynamics of life and see that there is no me and yes, the knots. So far nature has been used for free, and thanks to it we produce and live. However, in the panorama of the growth of the world population it has not recognized its due value.

In relation to irrigation, responsible for the waste and consequent commitment of the springs, to minimize the impacts of its inadequate use, Rebouças (2001) emphasizes that it is necessary a more efficient and rational planning of the use of irrigation and optimization of the equipment used. It can also reduce electricity costs.

Another recent practice in Brazil and which has been gaining strength is the use of reuse water to supply the need for irrigation of different food crops. Hespanhol (2002) complements that in several countries in which this technique is used, productivity increases significantly when well planned.

Any form of efficient use of water aimed at minimizing waste in the field depends directly on the planning made by the producer. The planning is indispensable in order to harmonize the various uses of water, enabling the different productive sectors, 
monitoring the quantity and quality of hydric resources, improving the levels of overall efficiency of use (PAZ et al., 2000).

Second (FURRIELA,2001) The first major challenge that arises not only for the rural producer, but also for all mankind is the awareness that there is no inexhaustible supply of drinking water on the planet. Some measures should be promoted to ensure the supply of water in quantity and acceptable standards. The great challenge of today is to reduce the level of water degradation by means of measures such as conservation, improvement of basic sanitation, reduction of pesticide use, cleaner industrial production and consumption management.

Each day is more evident the need to perceive water as an economic good, in which its management should be based on principles of economic efficiency, in a way that satisfies the demand from a perspective of sustainability.

It also adds that it is necessary to establish a new way of thinking and acting, adopting different habits, uses and customs, where the general objective is economic growth, based on the sustainable consumption of water, thus promoting the protection of Springs still preserved and the recovery of those already harmed, he points out that this is only not enough, and it is necessary to do much more to achieve this goal should therefore treat water as a social and environmental priority, since it is necessary to To take care of Brazilian water resources, as the increasing need for world water will bring the country the possibility to leverage its growth and development, and to hold an essential input to life and any productive activity.

\section{BIBLIOGRAPHICAL REFERENCES}

AGENDA 21. The Earth Summit Strategy to save our Planet. Ed. Daniel Sitarz, Earthpress, 321p. Boulder Colorado, 1994.

AGÊNCIA NACIONAL DAS ÁGUAS. Disponível em: <www.ana.gov.br> Acesso em: $20 / 07 / 2019$ 
Baía de todas as águas - Preservação e Gerenciamento Ambiental na Bacia Hidrográfica do Guaíba - Pró-Guaíba, RS/1998.

EBC. Disponível em: <www.ebc.com.br/.../mais-de-75-das-florestas-primarias-domundo-nao-existem-mais >Acesso em:19/07/2019

FURRIELA, R. B. EDUCAÇÃO PARA O CONSUMO SUSTENTÁVEL. Ciclo de Palestras sobre Meio Ambiente - Programa Conheça a Educação do Cibec/InepMEC/SEF/COEA, 2001.

HESPANHOL, I. Potencial de Reuso da Água No Brasil, Agricultura, Industria, Municípios, Recarga de Aquíferos. RBRH- Revista Brasileira Dos Recursos Hídricos. Vol. 7 n. 4, 2002

JUSBRASIL. Disponível em: <https://www.jusbrasil.com.br/topicos/10603350/artigo90-do-decreto-n-24643-de-10-de-julho-de-1934> Acesso em 20/07/2019

MUNDO DA EDUCAÇÃO. Disponível em: <https://mundoeducacao.bol.uol.com.br/geografia/consumo-agua-no-mundo.htm> Acesso em 12 de setembro de 2018.

OLIVEIRA, E. C. A Gestão Dos Recursos Hídricos Sob a Perspectiva da Descentralização. ANAP BRASIL - REVISTA CIENTÍFICA, ano 1 no 1, 2008.

PORTAL FMU. Disponível em: <https://portal.fmu.br/reciclagem-no-brasil-panoramaatual-e-desafios-para-o-futuro/> Acesso em: 20/07/2019

$\begin{array}{llll} & \text { RS. } & \text { Disponível }\end{array}$ $<w w w . p u c r s . b r / e d i p u c r s / o n l i n e / p l a n e t a a g u a / p l a n e t a a g u a . p d f>$ Acesso em: 20/07/2019

REVISTA EDUCAÇÃO AMBIENTAL EM AÇÃO. Disponível em: <http://www.revistaea.org/artigo.php?idartigo=1271> Acesso em: 17/07/2019

REBOUÇAS, A. C. Água e desenvolvimento rural. ESTUDOS AVANÇADOS, 2001. 
REBOUÇAS, A.C. Água no Brasil: Abundância, Desperdício e Escassez.BAHIASalvador, v. 13, n. ESPECIAL, p. 341-345, 2003 ANÁLISE \& DADOS

SILVA,J. S. Água e Agricultura Irrigada. Palestra-Seminário Agricultura Irrigada Com Desenvolvimento Sustentável-Universidade Federal De Uberaba-Em 24-09-2009. Disponível

em:

http:www.irrigacao.org.brdocdownloadAgua\%20Agricultura\%20Irrigada_JoseSilverio. pdf.. Acessado em: 20/07/2019

TUCCI, C. E. M. Gestão da água no Brasil. Brasília: UNESCO, 2001. 156p.(1. Hidrologia - Brasil II. Hespanhol, Ivanildo III. Cordeiro Netto,

VICTORINO, C. J. A. Planeta água morrendo de sede: uma visão analítica na metodologia do uso e abuso dos recursos hídricos. Porto Alegre: EDIPUCRS, 2007.231 p. (1. Água - Uso. 2. Água - Qualidade. 3. Recursos).

Submitted: June, 2019.

Approved: August, 2019. 